ISSN: 1110-5623 (Print) - 2090-0570 (Online)

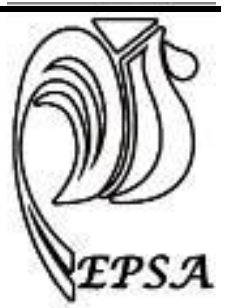

\title{
EFFECT OF HOUSING SYSTEM AND DIETARY BIOTIN SUPPLEMENTATION ON PRODUCTIVE PERFORMANCE, SOME BLOOD CONSTITUENTS AND ECONOMIC EFFICIENCY OF BENHA LINE CHICKEN \\ El-Garhy, O.H.M.; El-Gendi, G. M. and Okasha, H.M.A.
}

Anim.Prod. Dept., Fac of Agric, Benha Uni

*Corresponding auther: E-Mail; Osama.alsayed@ fagr.bu.edu.eg

Received: 01/03 /2019 Accepted: 24 /03 /2019

\begin{abstract}
This study aimed to investigate the effect of housing system and dietary biotin supplementation on productive performance, blood biochemical parameters and economic efficiency of Benha line chicken. A total of 224 chickens, 20 weeks old with similar body weight were used in this study, birds were equally divided into two main groups in a factorial arrangement design $(2 \times 4 \times 3)$. Pullets of the first group reared in cages. While, pullets of the second group reared on deep litter. The pullets of each group were subdivided into four subgroups (each of 25 females and 3 males) according to dietary biotin supplementation. Birds of the $1^{\text {st }}$ sub-group were fed on basal layer diet and considered as control, while the $2^{\text {nd }}, 3^{\text {rd }}$ and $4^{\text {th }}$ sub-groups fed basal diet supplemented with biotin at levels of 100,150 and $200 \mu \mathrm{g} / \mathrm{kg}$ feed, respectively. The results revealed that, pullets reared in cages significantly improve body weight, feed conversion, early to reach age at sexual maturity, egg production rate, egg weight, egg mass, absolute yolk weight compared to those reared on deep litter. While, pullets reared on deep litter had significantly improved feed consumption, egg shell thickness, plasma calcium, inorganic phosphorus and decreased plasma cholesterol and triglycerides compared to those reared in cages. Biotin supplementation at a level of $100 \mu \mathrm{g} / \mathrm{kg}$ feed had significantly increased body weight, egg weight, absolute and relative egg albumen weight, plasma inorganic phosphorus and decreased feed consumption compared to the other levels. While, pullets fed on diet supplemented $150 \mu \mathrm{g}$ biotin $/ \mathrm{kg}$ feed showed the improving in feed conversion, early sexual maturity, increased egg production, egg mass and plasma calcium compared with the other levels. In addition, birds fed diet supplemented with biotin at a level of $150 \mu \mathrm{g} / \mathrm{kg}$ feed and reared in cages recorded the highest economic efficiency $(219.04 \%)$, followed by those fed diet supplemented with biotin at a level of $100 \mu \mathrm{g} / \mathrm{kg}$ feed and reared on deep litter (141.37\%) compared to the other levels and control group. From the economic point of view, it could be concluded that rearing layer chickens in cages and fed on diet supplemented with biotin at a level of $150 \mu \mathrm{g} / \mathrm{kg}$ feed seemed to be adequate to achieve the favorable results, followed by those reared on deep litter and fed diet supplemented with biotin at a level of $100 \mu \mathrm{g} / \mathrm{kg}$ diet.
\end{abstract}

Key words: hens-housing system-biotin, productive performance- economic efficiency. 


\section{INTRODUCTION}

Housing systems of layer-hen have different schemes in modern production agriculture, including traditional cages, enriched cages, cage-free floor-raised house or aviary, or free range system. Each housing scheme has come into practice for different reasons as the scale of production has increased from the small rural farm to commercial-scale operations. Each system has beneficial services for producer, birds, and consumers. Alternative housing systems for laying hens must be designed to balance the health and the welfare of the birds with consumer preferences, the needs of the industry, and the impact on environment. Housing systems for laying hens have considerable effects on performance and production traits such as egg weight, feed efficiency and daily feed consumption (Suto et al., 1997). Egg quality is important for consumer appeal, and the economic success of a producer depends on the total number of eggs sold. Egg quality has a genetic basis and its parameters vary between strains of hens (Silversides et al., 2007) and also influenced by the housing system under which the hens are kept (Vits et al., 2005). Blood biochemical analysis is very important among the research because it supports and interprets the results of the research (Ozbey and Esen. 2007). The study of the variation in blood picture and constituents in the fowls sets an important foundation to the study of growth and egg production. Moreover, it helps in explaining the reaction of developed strains of poultry to their environments.

Biotin (known as vitamin, $\mathrm{H}$ ), a watersoluble vitamin belonging to the $\mathrm{B}$ complex group, is necessary for normal embryonic development and hatchability
(Whitehead et al., 1985). Its physiologically active form is linked to enzymes of great metabolic importance like biotin carboxylase and biotin decarboxylase and seems to be a keyenzyme in important processes like gluconeogenesis ,fatty acids and protein synthesis, controlling sclera-protein production. Because of its functions, this vitamin contributes to such important processes as growth, skin regeneration, bone development and reproduction, increasing feed conversion in animals (McMahon, 2002).

One of the new lines of chickens recently established in Egypt is Benha line. It was founded in 2011 as a synthetic line between the Egyptian Golden Montazah $(50 \%)$ and the White Leghorn (50\%). The procedure of establishment began mating males of Golden Montazah to females of White Leghorn and it was followed by three generations of "inter se" mating. The line has been selected to highly egg production and is characterized by high egg production, high resistance for Pasteurellosis and Salmonella diseases and the adaptability to hot climate condition (Iraqi et al., 2016). In addition, this line is widely spread within the commercial farms in Kalyoubia Governorate and Nile delta region. The studies concerning the management and rearing requirement of this new lines are scarce. Thus, the aim of this study was to evaluate the effect of housing system and dietary levels of biotin supplementation on egg production, quality traits, some blood constituents and economic efficiency for Benha line chickens as a new native chicken in Egypt. 
hens-housing system-biotin, productive performance- economic efficiency.

MATERIAL AND METHODS

Experimental design and bird's management:

This study was carried out at the Poultry Research Farm, Department of Animal Production, Faculty of Agriculture, Benha University, Egypt, started in November 2015 and terminated in May 2016. A total of 224 ( 200 hens and 24 cocks), Benha line chickens 20 weeks old and overall mean of body weight $(1742 \pm 20.1)$ were equally divided into two groups in a factorial experiment $(2 \times 4 \times 3)$ of completely random design. Pullets of the first group were housed in cages of laying battery two birds per cage of $48 \times 40 \times 40$ $\mathrm{cm}\left(960 \mathrm{~cm}^{2} / \mathrm{bird}\right)$. Pullets of the second group were kept on deep litter laying houses in a density of $900 \mathrm{~cm}^{2} /$ bird. Chickens of each group were then subdivided into four sub groups each of 25 females and 3 males according to dietary biotin supplementation. Pullets of the $1^{\text {st }}$ sub group were fed on basal layer diet and considered as control group, the $2^{\text {nd }}, 3^{\text {rd }}$ and $4^{\text {th }}$ sub groups were fed on basal diet supplemented with biotin at a level of 100,150 and $200 \mu \mathrm{g} / \mathrm{kg}$ diet, respectively. The basal layer diet (Table, 1) was formulated according to (NRC, 1994).

\section{Parameters estimation and data collection:}

Parameters were taken for pullets of all the experimental groups during the age at sexual maturity (when egg production reached 20\%), at the peak of egg production and at the end of the experimental period (lasted at the sex months after sexual maturity). Pullets of all the experimental groups were weighed monthly to the nearest $(\mathrm{g})$ until the age at sexual maturity, then at peak of egg production and at the end of the experiment. Feed consumption, feed conversion (F.C.), egg weight, rate of egg production, egg mass, the absolute and relative weights of egg component (albumen, yolk and shell weights) to the whole egg weight and shell thickness were measured at age of sexual maturity, the peak of egg production and at the end of the experimental period.

At the end of the experimental period heparinized blood sample were drown from four females taken randomly of each treatment. Plasma was separated by using centrifugation for 20 minutes of $2500 \mathrm{rpm}$ then all samples were transferred and stored in the deep freezer at approximately $-20^{\circ} \mathrm{C}$ until the time of biochemical analysis, blood samples was carried out by colorimetric method using commercial chemical kits (purchased from Bio-Merieux-Morcyletiols Charbon Mierels Rains/France) for determination of plasma calcium, inorganic phosphorous, cholesterol and plasma triglycerides. Finally, the economic efficiency (\%) was calculated from the input-output analysis based upon the differences in both selling revenue and feeding cost for each treatment group. Then, the relative Economic Efficiency was assumed as a relative Economic Efficiency (E.E.) to the control $=100 \%$.

Statistical analysis:

Analysis of variance was carried out using GLM procedure of SAS software (SAS, 2004). According to the following linear model:

$\mathrm{X}_{\mathrm{ijk}}=\mu+\mathrm{H}_{\mathrm{i}}+\mathrm{B}_{\mathrm{j}}+\mathrm{P}_{\mathrm{k}}+\mathrm{HB}_{\mathrm{ij}}+\mathrm{HP}_{\mathrm{ik}}+\mathrm{BP}_{\mathrm{jk}}$ $+\mathrm{HBP}_{\mathrm{ijk}}+\mathrm{e}_{\mathrm{ijk}}$

$\mathrm{X}_{\mathrm{ijk}}=$ the $\mathrm{k}^{\text {Th }}$ observation, $\mu=$ the overall mean.

$\mathrm{H}_{\mathrm{i}}=$ the effect of the housing system. (i, 12),

$\mathrm{B}_{\mathrm{j}}=$ the effect of the biotin supplementation. (j, 1-4) 
$\mathrm{P}_{\mathrm{k}}=$ the effect of the experimental period (k, 1-3)

$\mathrm{HB}_{\mathrm{ij}}=$ the interaction between $\mathrm{i}^{\text {th }}$ housing system and $j^{\text {th }}$ biotin supplementation

$\mathrm{HP}_{\mathrm{jk}}=$ the interaction between $\mathrm{i}^{\text {th }}$ housing system and experimental period $\mathrm{k}^{\text {th }}$

$\mathrm{BP}_{\mathrm{jk}}=$ the interaction between $\mathrm{j}^{\text {th }}$ biotin supplementation and experimental period $\mathrm{k}^{\text {th }}$

$\mathrm{HBP}_{\mathrm{ijk}}=$ the interaction among $\mathrm{i}^{\text {th }}$ housing system and $\mathrm{j}^{\text {th }}$ biotin supplementation as well as experimental period $\mathrm{k}^{\text {th }}$

$\mathrm{e}_{\mathrm{ijk}}=$ the experimental error.

Differences between treatments means were tested using Duncan multiple range test at significance level 0.05 (Duncan, 1955).

\section{RESULTS AND DISCUSSION}

Body weight (BW), feed consumption (FC) and feed conversion rate (FCR):

Results obtained in Table (2) showed that hens reared in cages was significantly increased the average of body weight $(1745.17 \mathrm{~g})$ compared to those reared on deep litter $(1671.44 \mathrm{~g})$. This result may attributed to the increases of metabolic processes and decreasing the loss of metabolic energy for birds present in cages, compared with those reared on deep litter that slightly increased BW. These results agree with those reported by EL-Gendi (1985) who found that pullets reared in cages almost gained more weight during the experimental period than those reared in deep litter laying houses. Pullets fed on diet supplemented with biotin at a level of $100 \mu \mathrm{g} / \mathrm{kg}$ diet showed higher BW (1736.40 g) compared with the other biotin levels and control group which recorded the lower BW averaged $1669.09 \mathrm{~g}$. This result may be attributed physiologically to active form is linked to biotin-dependent enzymes of great metabolic importance like biotin carboxylase and biotin decarboxylase and seems to be a key-enzyme in gluconeogenesis, lipogenesis, and fatty acid biosynthesis. Thus, it contributes in growth, bone development (Chen et al., 1994). Body weight was significantly influenced by biotin supplementation. This finding could be due to biotin being required in carbohydrate metabolism, fatty acids, protein synthesis, and nucleic acid metabolism formation (Whitehead, 1977). Similarly, Youssef et al., (2012) observed that the addition of biotin to the $\operatorname{diet}(2,000 \mu \mathrm{g} / \mathrm{kg}$ of diet $)$ of turkey pullets resulted in a higher BW compared with the control diet $(300 \mu \mathrm{g} / \mathrm{kg}$ of diet).It is seems quite logic to found that $\mathrm{BW}$ was increase by increasing in age from the age of sexual maturity to the end of the experiment.

The results concerning to FC and FCR (Table, 2), revealed that pullets reared in cages showed significantly lower feed consumption (105.71 g/hen/day) and higher improve in FCR (3.45 g feed/g egg). While pullets reared on deep litter laying houses showed higher FC (108.60 $\mathrm{g} / \mathrm{hen} /$ day) and lower FCR (3.90 g feed/ $\mathrm{g}$ egg). These results may be logic to attribute the significant variation in the average of feed consumption, due to housing system, to the variation in the amount of energy lost as a result of increasing muscular activity which is greater on deep litter laying houses than in cages. Obtained results agree with those reported by El-Anwer et al., (2009) who found that layer hens was significantly $(\mathrm{P} \leq 0.05)$ higher in feed consumption comparing under floor laying houses. However pullets kept in cages improved significantly feed conversion (3.45 g feed/ g egg) when compared with those kept on deep litter laying houses (3.90 g feed/ $\mathrm{g}$ egg). In addition, pullets fed on diet supplemented 
hens-housing system-biotin, productive performance- economic efficiency.

with biotin at a level of $150 \mu \mathrm{g} / \mathrm{kg}$ diet showed significantly lower FC (106.26 $\mathrm{g} /$ hen/day and higher improving in FCR (3.53 $\mathrm{g} \mathrm{feed} / \mathrm{g}$ egg), compared with the other biotin level and control group. It is clearly observed that FC increased by increasing of pullets age and the higher improve in FCR was observed at the period of peak of egg production $(2.86 \mathrm{~g}$ feed/ $\mathrm{g}$ egg). These results agree with those reported by Abdel-Mageed and Shabaan (2012) who found that biotin seems to play a more prominent role in the conversion of feed to eggs. Abd ElWahab et al., (2015) suggested that feeding the normal level of biotin was accompanied by the highest FCR (1.57).

Age at sexual maturity, Egg production rate, Egg weight and Egg mass:

Results presented in Table (3), revealed that pullets reared in cage reached to the age of sexual maturity earlier (142.76 day) than those reared on deep floor litter house (159.90 days). This may be due to the effect of housing system on growth rate of pullets and consequently on the age to reach sexual maturity. These results disagree with those found by ElAnwer et al., (2009) who reported that the age at sexual maturity of Silver Montazah and Matrouh chicken strains did not significantly affected by housing system. Concerning to the effect of housing system on egg production rate (\%/hen/day), egg weight (g) and egg mass ( $\mathrm{g} / \mathrm{hen} /$ day), it is clearly observed that pullets reared in cages had higher egg production rat, egg weight and egg mass $(61.00 \% /$ hen/day, $52.06 \mathrm{~g}$ and 32.19 $\mathrm{g} /$ hen/day, respectively) than those reared on deep floor house were (58.17\%/hen/day, $49.46 \mathrm{~g}$ and 28.90 $\mathrm{g} /$ hen/day, respectively). These results agreed with those reported by Wang et al., (2009) who found that egg production was higher under the battery cage system than in the deep litter and Petitte et al., (1982) who showed that broiler breeders housed in cages produce heavier eggs than those managed on litter floors. However, it disagree with those stated by El-Anwer et al., (2009) who showed that very slight increases in egg weight for hens reared on floor as compared with those kept in cages. This result seemed to be quite true since the pullets reared in cages previously mentioned has recorded higher average egg weight and egg production rate that are used in calculation of egg mass by multiplying egg number by egg weight (El-Gendi, 1985). Similar results were observed by El-Anwer et al., (2009) found that hens had recorded the highest values for egg mass under cages housing system. The results agreed with those showed by Balcazar (2014) reported that hens reared in cages had higher egg production after adjustment for mortality than those reared on floor deep letter especially during the onset of egg production indicating an earlier sexual maturity as well.

Pullets fed diet supplemented with biotin levels were earlier to reach the age of sexual maturity than control group. It was observed that Pullets fed on diet supplemented with $150 \mu \mathrm{g} / \mathrm{kg}$ diet was earlier (147.06 days) to reach the age of sexual maturity. However, pullets of control one was delayed in reaching to age of sexual maturity (154.05 day). The results were agreed with those reported by Taniguchi and Watanabe (2007) they demonstrated that the age at sexual maturity significant affected with biotin supplementation levels scenes it promote the early growing ovarian follicles, incorporated into the follicles, particularly in a large amount immediately before ovulation. It 


\section{El-Garhy, O.H.M et al.}

incorporated from the early stage to the growth stage of ovarian follicles that was stored in the protein-binding form and became available again immediately before the ovulation. Moreover, pullets fed diet supplemented with biotin at a level of $150 \mu \mathrm{g} / \mathrm{kg}$ recorded a higher egg production rate and egg mass $(62.51 \% / \mathrm{hen} /$ day and $31.97 \mathrm{~g} / \mathrm{hen} / \mathrm{day}$, respectively) while it recorded intermediate egg weight mounted (50.48 g) than those those received the other biotin levels and control group. This result may be attributed to the beneficial effect of biotin effects that improve metabolism pathway to increasing egg production rate. This result agreed with Chen et al., (1994) who found a greater egg production in biotin-fed turkey breeder hens aged 50 to $54 \mathrm{wk}$. also it is agree with those reported by AbdelMageed and Shabaan (2012) who showed that the increasing of biotin levels in diet had significantly improved egg mass compared to control. It is clearly observed that the egg production rate, egg weight and egg mass were significantly $(\mathrm{P}<0.001)$ varied due to vary in the periods of pullet's age. Egg production rate and egg mass increased by the advanced of pullet's age, recorded the higher values at the peak of egg production. This result was quite true since the potential pullets for egg production increase gradually after reach to the age of sexual maturity reaching to peak of egg production, then it was decrease gradually by the advancing of pullet's age. Egg weight increased by the advance of pullet's age till it reached to the highest average egg weight at the end of experimental period $(53.70 \mathrm{~g})$.

\section{Absolute and relative weights of egg components and shell thickness}

The results presented in Table (4) revealed that no significant effect was found in absolute and relative weights of egg shell, albumen and yolk for pullets of all experimental groups due to the effect of the housing system and biotin levels supplementation in diets. Pullets reared in cages showed slightly increase in absolute and relative weights of egg shell, albumen and yolk. While, eggs produced from pullets reared on deep litter showed lower absolute and relative egg components weights. However, pullets reared on floor deep litter showed higher shell thickness $(38.81 \mathrm{~mm})$ than those reared in cages $(34.43 \mathrm{~mm})$. The results agreed with those stated by El-Anwer et al., (2009) and Hassan (2001) who reported that no significant differences in relative egg albumin weight due to housing system. Moreover, Singh et al., (2009) who reported that, pullets reared on floor deep litter had significantly greater eggs albumen and yolk weights than cages ones. The increase in shell thickness of floor deep litter in the present study may attributed to the eggs size since as previously mentioned the pullets reared in floor laid smaller egg size than those laid by pullets reared in cage. The increase in egg shell thickness of floor laid eggs may be attributed to that birds reared on floor had access to the litter or waste as mineral source (AbdelRahman, 2000), which may be contributes in egg shell thickness. Concerning to the effect the different time of estimation on absolute and relative egg component weights and shell thickness, it was clearly observed that absolute and relative weights of shell and albumin increased gradually from the age at sexual maturity reaching to the maximum values 
hens-housing system-biotin, productive performance- economic efficiency.

at the peak of egg production, then, decreased towered the end of the experimental period. Opposite result was observed in absolute and relative weights of egg yolk.

\section{Plasmas calcium and inorganic phosphorus:}

Data obtained in Table, (5) showed that there were significant differences in plasma calcium and inorganic phosphorus levels due to the effect of housing system, biotin level and experimental period. Pullets reared on deep litter laying houses showed the higher averages of plasma calcium and inorganic phosphorus levels which mounted by $(7.01$ and $3.49 \mathrm{mg} /$ $\mathrm{dL}$, respectively) than those by birds reared in cages $(5.82$ and $2.96 \mathrm{mg} / \mathrm{dL}$, respectively). This result was agreed with those stated by El-Anwer et al., (2009) who reported that plasma calcium and inorganic phosphorus levels of layer hens had significantly increased at the $36^{\text {th }}$ wks of age due to rearing on floor deep litter. It is clearly observed that pullets fed diet supplemented with biotin at a level of 150 $\mu \mathrm{g} / \mathrm{kg}$ and $100 \mu \mathrm{g} / \mathrm{kg}$ recorded the higher averages of plasma calcium and inorganic phosphorus levels (6.97 and $3.79 \mathrm{mg} / \mathrm{dL}$, respectively) compared with the other biotin levels and control group. This result agrees with those reported by Afro et al., (2007) who stated that, the serum calcium and phosphorus levels were significantly higher in of birds fed on diet supplemented with biotin at a level of $300 \mu \mathrm{g} / \mathrm{kg}$ diet compared to control group. Plasma calcium and inorganic phosphorus has significant varied due to the different periods of estimation, the higher plasma calcium and inorganic phosphorus (6.74 and $3.55 \mathrm{mg}$ / $\mathrm{dL}$, respectively) were found at the end of experiment. While, the lower levels (5.97 and $2.88 \mathrm{mg} / \mathrm{dL}$, respectively) were recorded at the peak of egg production Plasma cholesterol and triglyceride:

The results obtained in Table, (5) showed that rearing pullets on cages significantly $(\mathrm{P}<0.001)$ increased plasma cholesterol $(164.54 \mathrm{mg} / \mathrm{dl})$ and insignificantly increased plasma triglycerides $(740.08 \mathrm{mg} / \mathrm{dl})$ than those reared on floor deep litter which recorded (118.46 and $660.81 \mathrm{mg} / \mathrm{dl}$, respectively) for plasma cholesterol and triglycerides, respectively. This result was agreed with those reported by El-Anwer et al., (2009) who showed that there was significant increase in plasma cholesterol level for pullets reared in cages during the period at sexual maturity and at the age of 36wks). Pullets fed on diet supplemented with biotin at a level of $150 \mu \mathrm{g} / \mathrm{kg}$ showed a higher plasma cholesterol level $(157.09 \mathrm{mg} / \mathrm{dl})$ followed by those received biotin at a level of $100 \mu \mathrm{g} / \mathrm{kg}$ $(144.44 \mathrm{mg} / \mathrm{dl})$. While pullets of control group showed the higher plasma triglycerides level (748.67 $\mathrm{mg} / \mathrm{dl})$ followed by those received biotin at a level of $200 \mu \mathrm{g} / \mathrm{kg}(722.35 \mathrm{mg} / \mathrm{dl})$. However, the lower plasma cholesterol (120.95) and triglycerides (629.26 mg/ dL) were recorded by pullets fed diet supplemented with biotin at a level of (200 and $150 \mu \mathrm{g} / \mathrm{kg}$, respectively). This may indicate the metabolic effects of treatment applied on the biosynthesis of either cholesterol from acetate or triglyceride as a result of change of some metabolic pathways. These results going in agree with those found by RevillaMonsalve et al., (2006) who reported that biotin supplementation a level of $15 \mu \mathrm{g}$ for 28 days, respectively decreased serum triglyceride concentration, but not total cholesterol. Plasma cholesterol and triglyceride levels had increased by 


\section{El-Garhy, O.H.M et al.}

advanced bird's age. The increment rate was higher in plasma triglycerides than plasma cholesterol, plasma cholesterol level increased by $5.94 \mathrm{mg} / \mathrm{dl}$ during the period from the onset of egg production to the end of the experimental period. However, plasma triglycerides increased by $98.84 \mathrm{mg} / \mathrm{dl}$ during the same period. This may be attributed to the higher rate of sexual steroids biosynthesis during the time of egg production. It is well known that cholesterol is the precursor of steroid hormones as well as of vitamin D3 and its metabolites; all are needed for egg formation.

\section{Economic efficiency:}

Data presented in Table, (6) revealed that the economic efficiency of different experimental groups for pullets reared on two different housing system (deep litter and battery cages) and feed on diet supplemented with different levels of biotin. The economic efficiency and relative economic efficiency values ranged from 0.15 to 0.92 and 51.72 to $219.04 \%$, respectively. The highest values were recorded by birds fed diet supplemented with different levels of biotin and reared in battery cages when compared with those reared on deep litter. The higher economic efficiency was found in the group of birds which fed on diet supplemented with biotin at a level of $150 \mu \mathrm{g} / \mathrm{kg}$ and reared in battery cage mounted $219.04 \%$, followed by those fed on diet supplemented with biotin at level of $100 \mu \mathrm{g} / \mathrm{kg}$ diet and reared on floor deep litter system (141.37\%) compared to control group which consider as $100 \%$. 
hens-housing system-biotin, productive performance- economic efficiency.

Table (1):Composition* and calculated nutritional value of starting, growing and basal layer diet.

\begin{tabular}{|l|c|c|c|}
\hline \multirow{2}{*}{\multicolumn{1}{|c|}{ Ingredients \% }} & \multicolumn{3}{c|}{ Ration } \\
\cline { 2 - 4 } & $\begin{array}{c}\text { Starting } \\
\text { 0-8 wks age }\end{array}$ & $\begin{array}{c}\text { Growing } \\
\text { 9-19 wks age }\end{array}$ & $\begin{array}{c}\text { Laying } \\
\text { 20 wks after }\end{array}$ \\
\hline Yellow corn & 65.00 & 63.00 & 66.00 \\
Soybean meal 44\% & 30.45 & 15.50 & 21.30 \\
Wheat bran & 0.65 & 17.78 & 2.94 \\
Di-calcium phosphate & 1.80 & 1.25 & 1.50 \\
Limestone & 1.40 & 1.80 & 7.60 \\
Salt & 0.30 & 0.30 & 0.30 \\
Vit \& Min. premix** & 0.30 & 0.30 & 0.30 \\
DI-Methionine & 0.10 & 0.07 & 0.06 \\
Total & 100.00 & 100.00 & 100.00 \\
\hline Calculated analysis: & \multicolumn{3}{|}{} \\
\hline Curd protein \% & 19.278 & 15.196 & 15.676 \\
M.E. (k cal/kg) & 2868.665 & 2689.866 & 2726.418 \\
Crude fiber \% & 3.723 & 4.472 & 3.329 \\
Crude fat \% & 2.723 & 3.051 & 2.766 \\
Calcium \% & 1.016 & 1.030 & 3.285 \\
Avail. Phosphorus \% & 0.485 & 0.397 & 0.412 \\
Lysin \% & 1.051 & 0.709 & 0.799 \\
Methionine \% & 0.428 & 0.326 & 0.334 \\
Cystin \% & 0.180 & 0.180 & 0.180 \\
Meth. + Cys. \% & 0.737 & 0.571 & 0.588 \\
\hline
\end{tabular}

*As recommended by NRC, (1994), which used during the period from sexual maturity to the end of the experimental period.

**Composition of premix in $3 \mathrm{~kg}$ is: Vit. A 10,000,000 IU, Vit. D3 2,000,000; Vit. E 10,000 mg, Vit. K3 1,000 mg, Vit. B1 1,000 mg, Vit. B2 4,000 mg, Vit. B6 1,500 mg, Vit. B12 $10 \mathrm{mg}$; Niacin 20,000 mg; Pantothenic acid 10,000 mg, Folic acid 1,000 mg, Biotin $50 \mathrm{mg}$, Choline chloride 500, $000 \mathrm{mg}$, Cu 3,000 mg, Iodine $300 \mathrm{mg}$, Fe 30,000 mg; Mn 40,000 mg, Zn 45,000 $\mathrm{mg}$, Selenium 100mg. 


\section{El-Garhy, O.H.M et al.}

Table (2): Least -square means and standard error for body weight (g), feed consumption (g/hen/day) and feed conversion ( $\mathrm{g}$ feed/g egg) as affected by studied factor.

\begin{tabular}{|c|c|c|c|c|}
\hline \multicolumn{2}{|c|}{ Items } & $\begin{array}{c}\text { Body weight } \\
\text { (g) }\end{array}$ & $\begin{array}{c}\text { Feed } \\
\text { consumption } \\
\text { (g/hen/day) }\end{array}$ & $\begin{array}{c}\text { Feed } \\
\text { conversion } \\
\text { (g feed/g egg) }\end{array}$ \\
\hline \multirow[t]{2}{*}{ Housing system } & Cages & $1745.17 \pm 78^{a}$ & $105.71 \pm 0.42^{b}$ & $3.45 \pm 0.01^{\mathrm{b}}$ \\
\hline & Deep litter & $1671.44 \pm 63^{b}$ & $108.60 \pm 0.42^{\mathrm{a}}$ & $3.90 \pm 0.01^{\mathrm{a}}$ \\
\hline \multirow{4}{*}{$\begin{array}{c}\text { Treatment } \\
\text { Biotin } \\
(\mu \mathrm{g} / \mathrm{kg})\end{array}$} & Control & $1669.09 \pm 19.5^{\mathrm{b}}$ & $108.84 \pm 0.60^{\mathrm{a}}$ & $3.88 \pm 0.02^{\mathrm{a}}$ \\
\hline & 100 & $1736.40 \pm 19.5^{\mathrm{a}}$ & $107.11 \pm 0.60^{b}$ & $3.68 \pm 0.02^{b}$ \\
\hline & 150 & $1727.29 \pm 19.5^{\mathrm{ab}}$ & $106.26 \pm 0.60^{b}$ & $3.53 \pm 0.02^{c}$ \\
\hline & 200 & $1700.43 \pm 19.5^{\mathrm{ab}}$ & $106.41 \pm 0.60^{b}$ & $3.63 \pm 0.02^{\mathrm{b}}$ \\
\hline \multirow{3}{*}{ Experimental_period } & Sexual maturity & $1587.08 \pm 16.9^{c}$ & $89.59 \pm 0.52^{b}$ & $4.31 \pm 0.02^{\mathrm{a}}$ \\
\hline & Peak* & $1740.12 \pm 16.9^{b}$ & $115.57 \pm 0.52^{\mathrm{a}}$ & $2.86 \pm 0.02^{\mathrm{c}}$ \\
\hline & End ${ }^{*}$ & $1797.71 \pm 16.9^{a}$ & $116.31 \pm 0.52^{\mathrm{a}}$ & $3.86 \pm 0.02^{\mathrm{b}}$ \\
\hline
\end{tabular}

Where; Peak* $=$ peak of egg production $\left(\right.$ at $8^{\text {th }}$ month of age) - End $^{*}=$ the end of the experimental period. ( $\mathrm{a}, \mathrm{b}, \mathrm{c}, \mathrm{d})$ means within each column with different superscripts are significantly different.

Table (3): Least -square means and standard error for Age at sexual maturity, egg production, egg weight and egg mass as affected by studied factors.

\begin{tabular}{|c|c|c|c|c|c|}
\hline \multicolumn{2}{|c|}{ Items } & $\begin{array}{c}\text { Age at sexual } \\
\text { maturity } \\
\text { (day) }\end{array}$ & $\begin{array}{c}\text { Egg- } \\
\text { production } \\
\text { (\%/hen/day) }\end{array}$ & $\begin{array}{c}\text { Egg weight } \\
\text { (g) }\end{array}$ & $\begin{array}{c}\text { Egg-mass } \\
\text { (g/hen/day) }\end{array}$ \\
\hline \multirow[b]{2}{*}{ Housing system } & & 142 & $61.00 \pm 0.61^{\mathrm{a}}$ & $52.06 \pm 0.29^{\mathrm{a}}$ & 32.1 \\
\hline & Dee & & 58.1 & $49.46 \pm 0.29^{b}$ & 28.9 \\
\hline \multirow{4}{*}{$\begin{array}{c}\text { Treatments } \\
\text { Biotin levels } \\
(\mu \mathrm{g} / \mathrm{kg})\end{array}$} & Control & 154.05 & $55.96 \pm 0.87^{c}$ & $51.48 \pm 0.41^{\mathrm{a}}$ & $29.05 \pm 0.63^{b}$ \\
\hline & 100 & $151.50 \pm 1.04^{b}$ & $58.90 \pm 0.87^{b}$ & $51.64 \pm 0.41^{a}$ & $30.82 \pm 0.63^{a b}$ \\
\hline & 15 & 147.06 & $62.51 \pm 0.87^{\mathrm{a}}$ & $50.48 \pm 0.41^{\mathrm{ab}}$ & $31.97 \pm 0.63^{\mathrm{a}}$ \\
\hline & 200 & $152.75 \pm 1.04^{\mathrm{b}}$ & $60.97 \pm 0.87^{a b}$ & $49.43 \pm 0.41^{b}$ & $30.34 \pm 0.63^{a b}$ \\
\hline \multirow{2}{*}{$\begin{array}{c}\text { Experimental } \\
\text { period }\end{array}$} & $\begin{array}{l}\text { Sexual } \\
\text { maturity }\end{array}$ & & $46.16 \pm 0.75^{c}$ & $45.12 \pm 0.36^{b}$ & 20.63 \\
\hline & $\begin{array}{l}\text { Peak* } \\
\text { End* }\end{array}$ & $\begin{array}{l}-- \\
--\end{array}$ & $\begin{array}{l}75.87 \pm 0.75^{a} \\
56.72 \pm 0.75^{b}\end{array}$ & $\begin{array}{l}53.46 \pm 0.36^{\mathrm{a}} \\
53.70 \pm 0.36^{\mathrm{a}}\end{array}$ & $\begin{array}{c}40.53 \pm 0.53^{a} \\
30.48 \pm 0.53^{b}\end{array}$ \\
\hline
\end{tabular}

Where; Peak* $=$ peak of egg production $\left(\right.$ at $8^{\text {th }}$ month of age) - End $*=$ the end of the experimental period. ( $a, b, c)$ means within each column with different superscripts are significantly different. 
Table (4): Least -square means and standard error ( $\mathrm{LSM} \pm$ S.E) for relative and absolute weights of shell, albumin and yolk and Shell thickness as affected by studied factors

\begin{tabular}{|c|c|c|c|c|c|c|c|c|}
\hline \multirow{2}{*}{\multicolumn{2}{|c|}{ Items }} & \multicolumn{2}{|c|}{ Shell weight } & \multicolumn{2}{|c|}{ Albumin weight } & \multicolumn{2}{|c|}{ Yolk weight } & \multirow{2}{*}{$\begin{array}{c}\text { Shell thickness } \\
(\mathrm{mm})\end{array}$} \\
\hline & & (g) & $\%$ & (g) & $\%$ & (g) & $\%$ & \\
\hline \multirow{2}{*}{$\begin{array}{l}\text { Housing } \\
\text { system }\end{array}$} & Cages & $6.72 \pm 0.27$ & $12.86 \pm 0.27$ & $31.76 \pm 0.51$ & $59.37 \pm 0.49$ & $15.68 \pm 0.27$ & $29.95 \pm 0.28$ & $34.43 \pm 1.09^{\mathrm{b}}$ \\
\hline & Deep litter & $6.29 \pm 0.26$ & $12.80 \pm 0.27$ & $30.65 \pm 0.51$ & $59.34 \pm 0.49$ & $14.91 \pm 0.27$ & $30.12 \pm 0.28$ & $38.81 \pm 1.09^{\mathrm{a}}$ \\
\hline \multirow{4}{*}{$\begin{array}{c}\text { Biotin levels } \\
(\mu \mathrm{g} / \mathrm{kg})\end{array}$} & Control & $6.50 \pm 0.38$ & $12.70 \pm 0.38$ & $31.03 \pm 0.72$ & $58.94 \pm 0.70$ & $15.51 \pm 0.38$ & $30.05 \pm 0.40$ & $34.67 \pm 1.55$ \\
\hline & 100 & $6.65 \pm 0.38$ & $12.93 \pm 0.38$ & $31.91 \pm 0.72$ & $59.64 \pm 0.70$ & $15.42 \pm 0.38$ & $29.80 \pm 0.40$ & $35.89 \pm 1.55$ \\
\hline & 150 & $6.53 \pm 0.38$ & $12.96 \pm 0.38$ & $31.26 \pm 0.72$ & $59.34 \pm 0.70$ & $15.08 \pm 0.38$ & $29.83 \pm 0.40$ & $37.52 \pm 1.55$ \\
\hline & 200 & $6.35 \pm 0.38$ & $12.72 \pm 0.38$ & $30.64 \pm 0.72$ & $59.39 \pm 0.70$ & $15.16 \pm 0.38$ & $30.47 \pm 0.40$ & $37.18 \pm 1.55$ \\
\hline \multirow{3}{*}{$\begin{array}{l}\text { Experimental } \\
\text { period }\end{array}$} & $\begin{array}{c}\text { Sexual } \\
\text { maturity }\end{array}$ & $6.12 \pm 0.33$ & $13.43 \pm 0.43^{\mathrm{a}}$ & $26.42 \pm 0.62^{b}$ & $58.49 \pm 0.60^{\mathrm{a}}$ & $12.83 \pm 0.33^{b}$ & $28.32 \pm 0.34^{\mathrm{c}}$ & $32.47 \pm 1.34^{\mathrm{b}}$ \\
\hline & Peak* & $6.77 \pm 0.33$ & $12.69 \pm 0.43^{\mathrm{ab}}$ & $33.68 \pm 0.62^{\mathrm{a}}$ & $60.07 \pm 0.60^{\mathrm{a}}$ & $16.41 \pm 0.33^{\mathrm{a}}$ & $30.23 \pm 0.34^{b}$ & $38.01 \pm 1.34^{\mathrm{a}}$ \\
\hline & End & $6.63 \pm 0.33$ & $12.37 \pm 0.43^{\mathrm{b}}$ & $33.53 \pm 0.62^{\mathrm{a}}$ & $59.50 \pm 0.60^{\mathrm{b}}$ & $16.91 \pm 0.33^{\mathrm{a}}$ & $31.55 \pm 0.34^{\mathrm{a}}$ & $38.41 \pm 1.34^{\mathrm{a}}$ \\
\hline
\end{tabular}

Where; Peak* $=$ peak of egg production (at 8
different superscripts are significantly different. 
Table (5): Least - square means and standard error ( LSM \pm S.E) for serum calcium, inorganic phosphorus, plasma cholesterol and triglycerides as affected by studied factors

\begin{tabular}{|c|c|c|c|c|c|}
\hline \multicolumn{2}{|c|}{ Items } & $\begin{array}{l}\text { Calcium } \\
(\mathrm{mg} / \mathrm{dL})\end{array}$ & $\begin{array}{c}\text { Inorganic phosphorus } \\
(\mathrm{mg} / \mathrm{dL})\end{array}$ & $\begin{array}{c}\text { cholesterol } \\
(\mathrm{mg} / \mathrm{dl})\end{array}$ & $\begin{array}{c}\text { Triglycerides } \\
\text { (mg/dl) }\end{array}$ \\
\hline Housing_system & $\begin{array}{c}\text { Cages } \\
\text { Deep litter }\end{array}$ & $\begin{array}{l}5.82 \pm 0.16^{\mathrm{b}} \\
7.01 \pm 0.16^{\mathrm{a}}\end{array}$ & $\begin{array}{c}2.96 \pm 0.15^{\mathrm{b}} \\
3.49 \pm 0.15^{\mathrm{a}}\end{array}$ & $\begin{array}{c}164.54 \pm 8.16^{\mathrm{a}} \\
118.46 \pm 8.16^{\mathrm{b}}\end{array}$ & $\begin{array}{l}740.08 \pm 32.48 \\
660.81 \pm 32.48\end{array}$ \\
\hline $\begin{array}{l}\text { Biotin levels } \\
(\mu \mathrm{g} / \mathrm{kg})\end{array}$ & $\begin{array}{c}\text { Control } \\
100 \\
150 \\
200\end{array}$ & $\begin{array}{c}5.95 \pm 0.23^{\mathrm{b}} \\
6.28 \pm 0.23^{\mathrm{b}} \\
6.97 \pm 0.23^{\mathrm{a}} \\
6.47 \pm 0.23^{\mathrm{ab}}\end{array}$ & $\begin{array}{c}3.04 \pm 0.22^{\mathrm{bc}} \\
3.79 \pm 0.22^{\mathrm{a}} \\
3.52 \pm 0.22^{\mathrm{ab}} \\
2.56 \pm 0.22^{\mathrm{c}}\end{array}$ & $\begin{array}{c}143.52 \pm 11.54^{\mathrm{ab}} \\
144.44 \pm 11.54^{\mathrm{ab}} \\
157.09 \pm 11.54^{\mathrm{a}} \\
120.95 \pm 11.54^{\mathrm{b}}\end{array}$ & $\begin{array}{c}748.67 \pm 45.94 \\
701.51 \pm 45.94 \\
629.26 \pm 45.94 \\
722.35 \pm 45.94\end{array}$ \\
\hline $\begin{array}{l}\text { Experimental } \\
\text { period }\end{array}$ & $\begin{array}{c}\text { Sexual maturity } \\
\text { Peak* } \\
\text { End }\end{array}$ & $\begin{array}{l}6.54 \pm 0.19^{\mathrm{a}} \\
5.97 \pm 0.19^{\mathrm{b}} \\
6.74 \pm 0.19^{\mathrm{a}}\end{array}$ & $\begin{array}{c}3.26 \pm 0.19^{\mathrm{ab}} \\
2.88 \pm 0.19^{\mathrm{b}} \\
3.55 \pm 0.19^{\mathrm{a}}\end{array}$ & $\begin{array}{c}142.08 \pm 10.00 \\
134.41 \pm 10.00 \\
148.02 \pm 10.00\end{array}$ & $\begin{array}{l}723.73 \pm 39.78^{a} \\
555.04 \pm 39.78^{b} \\
822.57 \pm 39.78^{a}\end{array}$ \\
\hline
\end{tabular}

Where; Peak ${ }^{*}=$ peak of egg production (at $8^{\text {th }}$ month of age) - End $*=$ the end of the experimental period. $(a, b, c)$ means within each column with different superscripts are significantly different. 
Table (6): Economic Efficiency of experimental groups as affected by studied factors at the end of the experiment

\begin{tabular}{|c|c|c|c|c|c|c|c|c|}
\hline \multirow{3}{*}{ Items } & \multicolumn{8}{|c|}{ Housing system } \\
\hline & \multicolumn{4}{|c|}{ Cages } & \multicolumn{4}{|c|}{ Floor } \\
\hline & $\mathrm{C}^{*}$ & $\mathrm{~T}_{1}^{*}$ & $\mathrm{~T}_{2}{ }^{*}$ & $\mathrm{~T}_{3}{ }^{*}$ & $\mathrm{C}$ & $\mathrm{T}_{1}$ & $\mathrm{~T}_{2}$ & $\mathrm{~T}_{3}$ \\
\hline Price feed $\mathrm{Kg}(\mathrm{LE})^{(1)}$ & 3.45 & 3.53 & 3.56 & 3.60 & 3.45 & 3.53 & 3.56 & 3.60 \\
\hline Total feed intake/hen $(\mathrm{kg})$ & 19.37 & 18.96 & 18.91 & 18.84 & 19.80 & 19.59 & 19.33 & 19.46 \\
\hline Total feed cost/hen(LE) & 66.83 & 66.93 & 67.32 & 67.82 & 68.31 & 69.15 & 68.81 & 70.1 \\
\hline Total No. of egg/hen & 102 & 103 & 139 & 105 & 95 & 105 & 91 & 87 \\
\hline Price of total egg product / hen (LE) & 95.2 & 95.79 & 129.27 & 97.65 & 88.35 & 97.65 & 84.63 & 80.91 \\
\hline Net revenue /hen $(\mathrm{LE})^{(2)}$ & 28.37 & 28.86 & 61.95 & 29.83 & 20.04 & 28.5 & 15.82 & 10.81 \\
\hline Economic efficiency (EE) ${ }^{(3)}$ & 0.42 & 0.43 & 0.92 & 0.43 & 0.29 & 0.41 & 0.23 & 0.15 \\
\hline Relative economic efficiency ${ }^{(4)}$ & 100 & 102.38 & 219.04 & 102.38 & 100 & 141.37 & 79.31 & 51.72 \\
\hline
\end{tabular}

${ }^{*} \mathrm{C}=$ control group, $\mathrm{T}^{*}, \mathrm{~T} 2 *$ and $\mathrm{T} 3 *=100,150$ and $200 \mu \mathrm{g}$ biotin/ $\mathrm{Kg}$ diet, respectively.

(1) L.E = 1 Egyptian pound.

(2) Net revenue/ hen (E.E) = price of total egg produced / hen (L.E) - total feed cost / hen (L.E).

(3) Economic Efficiency (E.E.) = Net revenue / price of feed intake.

(4) Relative Economic Efficiency: assuming that the relative Economic Efficiency (E.E.) of the control=100\%. 


\section{REFERENCE}

Abd El-Wahab, A., Radko, D., and Kamphues, J. 0215. High dietary levels of biotin and zinc to improve health of foot pads in broilers exposed experimentally to litter with critical moisture content. Poultry science, 92(7), 1774-1782.

Abdel-Mageed, M. A. A., \& Shabaan, S. A. M. 2012. Effect of supplemental biotin on the performance of aged fayoumi hens and progeny performance. Egypt. Poult. Sci. J. 32: 895-908.

Abdel-Rahman, A. 2000. Effect of Naked Neck gene (Na) and housing system on egg production performance of sharkasi chickens under subtropical conditions; Egypt, Poult Sci., 20:905926.Acidophilus.

Afro Quarantelli, Antonio Cacchioli, Simone Romanelli, Federico Righi1, Irene Alpigiani, Carlo Gabbi.2007. Effects of different levels of dietary biotin on the performance and bone structure of broilers. Italian Journal of Animal Science, 6:1, 5-7, DOI: 10.4081/ijas.2007.5

Balcazar, P. E. E. 2014. The effects of limestone particle size on bone health and performance of pullets and hens in conventional cage and alternative housing systems (Doctoral dissertation, The University of Nebraska-Lincoln).

Chen, F., S. L. Noll, and P. E. Waibel. 1994. Dietary biotin and turkey breeder performance. Poult. Sci. 73:682-686.

Duncan, D.B. 1955. Multiple range and multiple F tests. Biometrics.11: 1-42.

El - Gendi, G. M.,1985. Some factors affecting productive efficiency in chicken under subtropical conditions. M.Sc. Thesis, Fac. of Agric.,
Moshtohor, Zagazig Univ. Benha branch, Egypt.

El-Anwer. M. M. A., Salem Amina, M., Abou-Eitta, A., and Al-Kotait, H. A. 2009. A comparative study between two local strains under cage and floor housing systems. Egypt Poultry Science, 29, 439-464.

Hassan, A.H.A. 2001. Egg quality traits as affected by strain, housing system and time of egg collection. J. Prod. \& Dev., 6:167-179.

Iraqi, M.M., Khalil, M.H. and El Attrouny M.M. 2016. The phenotypic and productive characterization of benha-line chicken under Egyptian conditions. Egypt. Poult. Sci. Vol (36) (III): 685-693.

McMahon, R. J., 2002. Biotin in metabolism and molecular biology. Annu. Rev. Nutr., 22: 221-239.

Mikolajcik, E. M., and Hamdan, I. Y. 1975. Lactobacillus acidophilus. II. Antimicrobial agents. Cult. Dairy Prod. J, 10(1), 18-20.

NRC 1994. Nutrient requirements of Poultry National Research Council. $9^{\mathrm{N}}$ reviseded .Nat. Aced Press, Washington, D.C. USA.

Ozbey, O. and Esen, F. 2007 b. The effects of different breeding systems on egg productivity and egg quality characteristics of Rock Partridges. Poult. Sci., 86:782-785.

Petitte, J. N., Hawes, R. O., \& Gerry, R. W. 1982. The influence of flock uniformity on the reproductive performance of broiler breeder hens housed in cages

Revilla-Monsalve, C., Zendejas-Ruiz, I., Islas-Andrade, S., Báez-Saldaña, A., Palomino- Garibay, M.A., Hernández-Quiróz, $\quad$ P.M., Fernandez-Mejia, C., 2006. Biotin supplementation reduces plasma 
hens-housing system-biotin, productive performance- economic efficiency.

triacylglycerol and VLDL in type 2 diabetic patients and in non-diabetic subjects with hypertriglyceridemia. Biomed. Pharmacotherapy. 60,182185.

SAS Institute. 2004. SAS Proprietary Software Release 9.0. SAS Inst. Inc., Cary, NC.

Silversides, F.G.; Shaver, Mc. Q.D. and Song, Y. 2007. Pure line laying chickens at the Agassiz Research Center. Anim. Gen. Res. Inform., 40: $79-85$.

Singh, R.; Cheng, K.M. and Silversides, F.G. 2009. Production performance and egg quality of four strains of laying hens kept in conventional cages and floor pens. Poult. Sci. 88:256-264.

Suto, Z.; Horn, P. and Ujvari, J. 1997. The effect of different housing systems on production and egg quality traits of Brown and Leghorn type layers. Acta. Agaria. Kaosvariensis., 1:29-35.

Taniguchi, A., and Watanabe, T. 2007. Roles of biotin in growing ovarian follicles and embryonic development in domestic fowl. Journal of nutritional science and vitaminology, 53(6), 457463.

Vits, A.; Weizenburger, D.; Hamann, H. and Distl, O. 2005. Influence of different small group systems on production traits, egg quality and bone breaking strength of laying hens. First communication: Production traits and egg quality. Zuchtungskunde., 77:303323.

Wang, X. L., Zheng, J. X., Ning, Z. H., Qu, L. J., Xu, G. Y., \& Yang, N. 2009. Laying performance and egg quality of blue-shelled layers as affected by different housing systems. Poultry science, 88(7), 1485-1492.

Whitehead, C. C. 1977. The use of biotin in poultry nutrition. World's Poultry Science Journal, 33(3), 140154.

Whitehead, C. C., R. A. Pearson, and K. M. Herron. 1985. Biotin requirements of broiler breeders fed diets of different protein content and effect of insufficient biotin on the viability of progeny. Br. Poult. Sci. 26:73-82.

Youssef, I. M. I., Beineke, A., Rohn, K., and Kamphues, J. 2012. Influences of increased levels of biotin, zinc or mannan oligosaccharides in the diet on foot pad dermatitis in growing turkeys housed on dry and wet litter. Journal of animal physiology and animal nutrition, 96(5), 747-761. 
El-Garhy, O.H.M et al.

$$
\text { الملخص العربي }
$$

\section{تأثير نظام الإسكان والتظذية على البيوتين على الاداء الانتاجى ، بعض مكونات الام والكفاءة الاقتصادية لخط دجاج الأبن الأنها}

\section{اسامة حسن منصور الجارحى، جعفر محمود الجندى و حمادة محمد احمد عكاشة}

$$
\text { قسم الانتاج الحيو انى ـ كلية الزر اعة - جامعة بنها }
$$

هدفت هذه الدراسة إلى تقييم تأثثر نظام الإسكان والتخذية على البيوتين على الأداء الإنتاجي وبعض مقاييس الدم

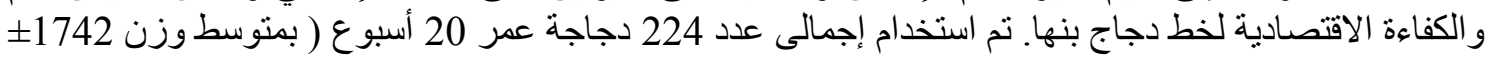

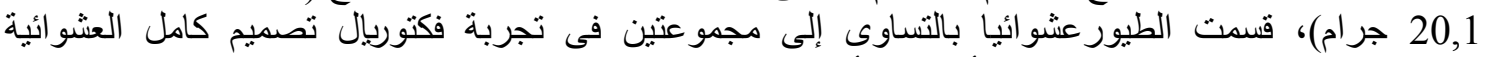

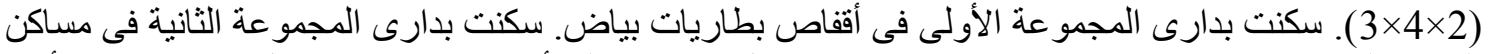

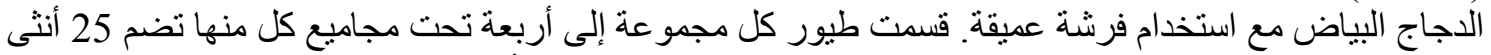

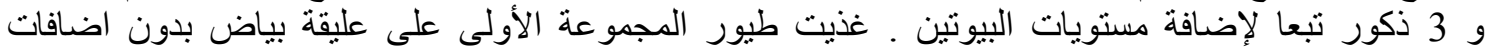

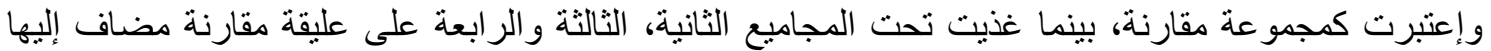

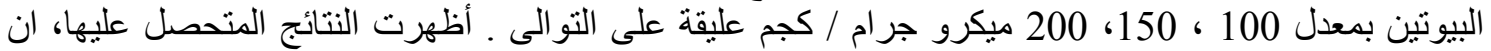

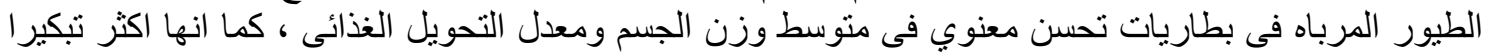

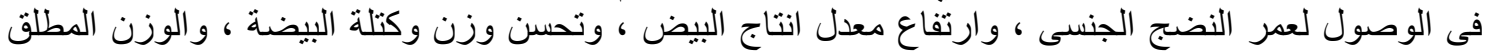

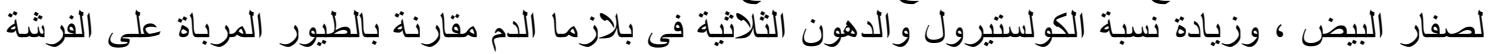

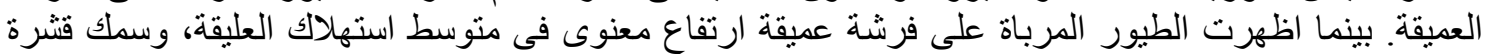

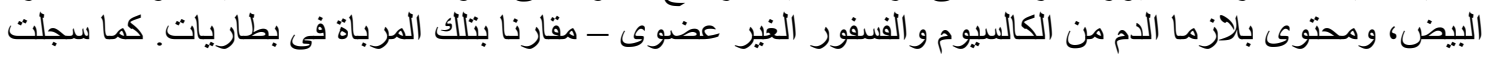

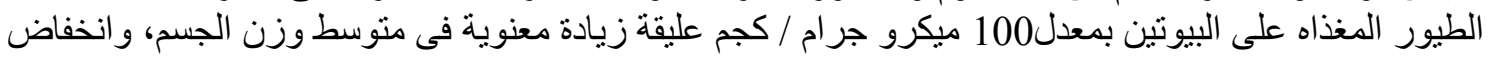

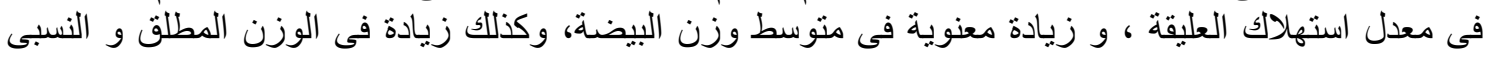

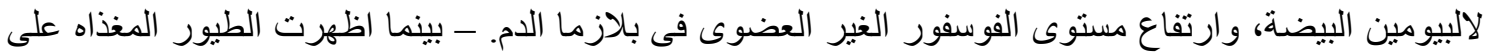

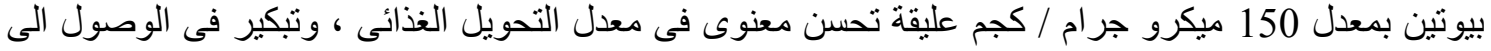

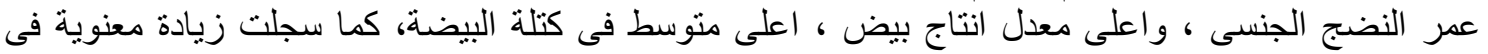

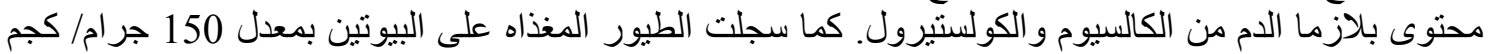

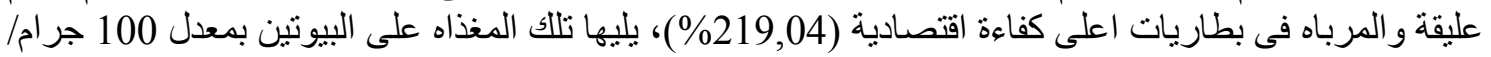

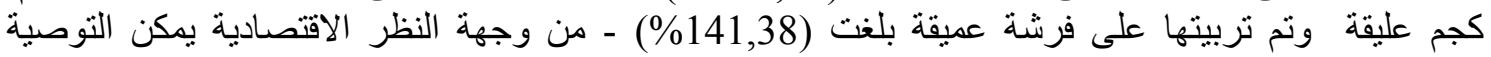

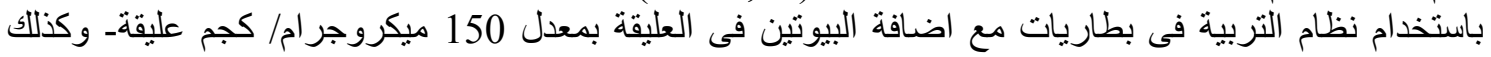

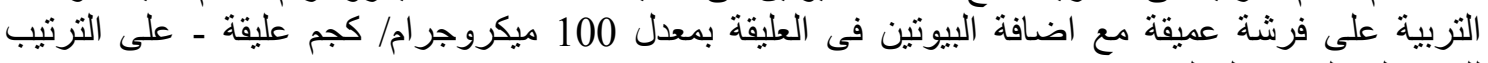
للحصول على افضل النتائج. 